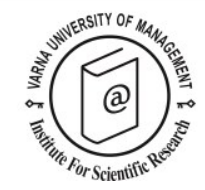

\title{
Rodanthi Tzanelli (2016). Thanatourism and cinematic representation of risk. Abingdon: Routledge. ISBN 978-113862564-4, $194 \mathrm{pg}$.
}

\author{
Reviewed by Maximiliano E. Korstanje ${ }^{1}$
}

Received: 06/03/2016

1 University of Palermo Argentina

(C) 2016 Varna University of Management. All rights reserved

Citation Rodanthi Tzanelli (2016). Thanatourism and cinematic representation of risk. Abingdon: Routledge. ISBN 978-113862564-4, 194 pg. Reviewed by Maximiliano E. Korstanje, European Journal of Tourism Research 14, pp. 137-139

Although some voices recently emphasize on the end of global tourism worldwide, Seniour sociologist at University of Leeds, UK, Rodanthi Tzanelli sees the opposite. In a world of risks where even tourism (the most prominent industries indicated by neoliberallism) turns out seriously affected, she proposes a more than interesting diagnosis. The distance between sightseers and natives, which originally characterized tourism or heritage seekers, is mutating to new forms. As the previous backdrop, her recent book entitled Thana-tourism and Cinematic Representation of Risk and recently published by Routledge, she discusses to what an extent the concatenation of different disasters that are covered by the media and cinema correspond with a much deeper mechanism of surveillance to keep the work-force under control. At a closer look, creativity allows the destructive creation process in order for capitalism to be recycled, which means that each disaster which takes hit in a community paves the pathways for the rise of a new international destination.
The question whether dark tourism surfaced over recent decades as one of the trends of leisure consumption in zones of extreme poverty or areas of ghettoization resulted from decades of an exploitative logic exported during the facet of colonization during XIXth and XXth centuries. However, instead of provoking a collective awakening, cinema offers a biased diagnosis to the material asymmetries produced by the expansion of capitalism. It is important not to lose the sight that in these new global landscape, massdeath seems to be a key factor in the intersection of consumption with death. This begs a more than interesting point which is not addressed by specialized literature, is West a sadist civilization?

To respond this question, although not formulated in the same terms, Tzanelli introduces readers in a ground-breaking argument, oddly capitalism has moved to a new stage where artists devote their efforts in drawing a fictional landscape of doom-days. While stories of the end of the world or zombie apocalyptic viruses captivate our 
RodanthiTzanelli (2016). Thanatourism and cinematic representation of risk. Abingdon: Routledge. ISBN 978-113862564-4, 194 pg. Reviewed by Maximiliano E. Korstanje, European Journal of Tourism Research 14, pp. 137-139

attention, the world is far from facing a total destruction. What Tzanelli suggests is that the allegories of death serve to replicate the authority of status-quo. The inflation of different risks which oscillates from natural disasters to terrorism, evinces that the holiday-making and leisure practices as tourism are next to disappear but paradoxically, dark tourism still revitalizing the giftexchange process that made capitalism feasible. In retrospect, the instrument of surveillance orchestrated by capitalism appeal to the metaphor of undesired guests where working-migrants are stereotyped as zombies, monsters, terrorists or even viruses which may very well threaten the current civilized social order. Since the concept of risk which is theatricalized by the film-related industries allows the imposition of allegories to see the capitalist ethos as one of the best possible worlds, entrepreneurship surfaces as a vehicle to invest first world citizens of an exceptional aura. Therefore, dark tourism as it is detailed in second chapter takes part of a communal "memory-work" as a life lived in conditions that give others a pretext to feel superior, in terms of Tzanelli a life lived in the periphery. Dark tourism serves as the locus "of a polyphonic hermeneutics" which is based on a multiple sense of places, anticipating the "end of tourism". Whether the neoliberal doctrine poses in tourism a fertile instrument to enhance the governability of nations, many questions remain open to understand why genocides, political instability and inter-ethnical wars are its immediate consequences. Additionally, as Tzanelli puts it, imagination adjoins to the power of capital to exert a considerable influence over citizens in molding hopes, fears and desires of daily life. Throughout third chapter, Tzanelli delves into a much deep examination of films Children of Men, 28 Weeks Later, Elysium and District 9 to crystalize one the best section of the book where she deploys her unlimited resources as content-analyst to hold the following polemic axiom: slum and dark tourism are central places where spectatorship aesthetically enlarges the gap between have and have-nots. Expiating their burdens to be part of a society which exploited "Others", dark tourists reify a commoditized version of colonialism tailored for white and western subjectivities.

As this argument is given, chapter 4 and 5 center on the dystopia of fiction to give further details how the identity of nation is commoditized by the cinematic gaze. The conjuncture or environmental conditions, where movies are filmed, correspond with constituencies and representations externally designed but internally engaged by in-group members. At the periphery nations accept an allegory that explains further on their dangerosity, but in blaming others, central nations face an atmosphere of terror given by the internal enemy. In fact, central economies have serious problems to control forced migration not only because they feel the enemies of democracy are within, but also because they have developed a radical image of the world, as an uncivilized and hostile place which deserves to be disciplined. Not surprisingly, the genealogies of District 9 in getthorised South Africa offers a good explanation to this. The legacy of colonialism as well as the stereotypes, prejudice even racism is interwoven into an essentialised culture, where the non-European other is seen as victim whose story should be told. But in so doing, the real reasons by means colonialism expanded and African cultures were ushered in pauperism are cynically covered. Landscapes of dark tourism and Thana-tourism are magisterially addressed in fifth chapter. In fact, dark tourism poses a fertile ground for capitalism to trade with human suffering creating a representational (but unreal) discourse of past or colonial past. Last but not least, the final section explores the impossibility of artists for designing social reality since "they are unable to speak for other who they represent", Tzanelli adheres.

The main thesis of this disturbing and devastating dissection of capitalism is that any of the cinematic representations, which often simulates the end of tourism, placed a hegemonic discourse aimed at disciplining the non-European Other; this exhibits an implicit but powerful racism that periphery is unable to break. One of the aspects where Tzanelli makes a substantial contribution on dark 
RodanthiTzanelli (2016). Thanatourism and cinematic representation of risk. Abingdon: Routledge. ISBN 978-113862564-4, 194 pg. Reviewed by Maximiliano E. Korstanje, European Journal of Tourism Research 14, pp. 137-139

tourism issues rests on the intersection of cinema as a producer of pseudo-realities. In the movies, the act of imagining risky situations really does not forecast potential problems or ethical dilemmas of humankind, but producing them in one direction for natives to adopt a "fixed identity" in observance of their skills and possibilities to struggle against the hegemony of central nations. Lastly, she masterfully worked the conception of a new capitalism, which in consonance with Korstanje who coined the term "Thana-Capitalism", gives insight on how elite developed a wider disciplinary mechanism reinforcing its sentiment of exceptionalism over the working class. Since I am still alive, the death of others reminds how special I am. If risk was the commodity of risksociety, death is the touchstone of Thanacapitalism. In sum, Tzanelli's project not only sounds trailblazing but it ignites a hot-debate in an interesting direction which merits to be continued in next decades.

\section{Reference}

Korstanje M. E (2015) A Difficult World: examining the roots of capitalism. New York, Nova Science Pubs. 